lard, Canada Research Chair in Landscape Conservation, Université de Moncton. "Our students also get the opportunity to sit in on various company advisory committee meetings so they can see first hand how forests are managed in the real world. They get a real appreciation for the issues - the day-to-day challenges that forest managers have to deal with on a daily basis."

After nearly a decade of student training, the SFM Network is beginning to reap some major benefits. Network students are graduating and being employed in a number of sectors including government and consulting agencies. Many are now established researchers at various Canadian universities, or with organizations like Natural Resources Canada, Canadian Forest Service as is Research Scientist Dr.Vernon Peters. Interestingly in 2004-2005, a quick count yielded 12 former students who are now sufficiently established to compete for Network funding as either a principal investigator or as a research collaborator. Several proposals provided by these former students for the most recent Network competition merited funding!

As predicted when the Network began, lessons learned from the past nine years of research have led to evolutionary changes in the SFM Network's research program. One of the most significant examples is the need for larger and more integrated project teams as the most effective way to deal with the ecological, economic and social aspects of sustainability. When it comes to training HQP, previous SFM Network students now working as researchers and managers have helped define new questions and new ways to enrich the next round of research partnerships. Students joining the SFM Network today are now being trained to recognize and learn from these experiences as a guide toward creating their own exciting research futures in sustainable forest management.

\section{Bruce Macnab, HQP Research Administrator, SFM Network Marvin Abugov, Communications Manager, SFM Network E-mail: bruce.macnab@ualberta.ca, mabugov@ualberta.ca}

\title{
Aboriginal Forestry News
}

\section{A Growing Need for Forestry Professionals}

The National Aboriginal Forestry Association (NAFA) has just released a video for Aboriginal youth encouraging them to seek out professional careers in forestry. The video in CD Rom format showcases young Aboriginal professionals who work in various areas of land management related to forestry. The video was produced by NAFA in partnership with Inter-INDigital Entertainment and P.B. Communications with funding assistance from the First Nation Forestry Program and Aboriginal Business Canada.

The National Aboriginal Forestry Association (NAFA) has emphasized the need for forestry training and education initiatives since its establishment in 1991. To document the need, NAFA completed the Aboriginal Forestry Training and Employment Review (AFTER) in 1995 and has since completed an analysis of forestry labour market trends that demonstrates the need for Aboriginal professional development in the forest sector. NAFA's work has also revealed that Aboriginal foresters are essential to the development of sustainable Aboriginal communities reflecting the Aboriginal forest land ethic.

Currently, First Nations, Tribal Councils, forestry enterprises, development corporations and other Aboriginal organizations are looking outside the Aboriginal community to hire forestry staff or to contract with forestry consultants. NAFA estimates that total expenditures to hire non-Aboriginal forestry expertise equates to more than 500-person years of work annually. NAFA studies estimate that the need for foresters in Aboriginal communities will likely double in the next ten years due to increased Aboriginal control over larger land bases resulting from the settlement of land claim issues, treaty implementation and the acquisition of forest tenures and forest-based businesses.

There are currently only an estimated 60 Professional Foresters in Canada who are of Aboriginal ancestry. This is an extremely small number considering $80 \%$ of Aboriginal communities are located within the forest regions of Canada and roughly 1.4 million hectares of forested land is located on Indian reserves. Canada's total forested land base is 417.6-million hectares and is managed primarily by non-Aboriginal foresters.

Becoming a professional forester requires a commitment to education. Besides entering a university program straight from high school, some Aboriginal students start at the college level to gain a forestry technician diploma and from there continue on to degree-granting institutions.

Lakehead University is currently the only degree-granting institution in Ontario offering an undergraduate forestry program accredited by the Canadian Forestry Accreditation Board. Other universities with undergraduate forestry programs include the University of Alberta, University of British Columbia, University of Northern British Columbia, University of Moncton, University of New Brunswick and Laval University. The University of Toronto offers graduate studies in forestry and a Masters in Forest Conservation, which encourages cross-overs from other faculties or disciplines.

The types of jobs available in the forest sector include anything from company forester to environmental law. The list of opportunities in forestry is vast and exciting and enables young Aboriginal people to work close to home and on behalf of their communities.

Legal and political developments in Aboriginal rights issues are leading to new opportunities for Aboriginal people to perform a greater role in forest resource management. The legal recognition of Aboriginal title and treaty rights requires that Aboriginal people have a greater say and share in the forest-based economy.

The challenge is to meet the skills shortage faced by Aboriginal communities in the forest sector while building Aboriginal capacity and resources that will ultimately benefit the entire community.

Recent Court decisions in Canada, such as Delgamuukw, have set a new direction for resource development and land use. Governments and Industry both have responsibilities now to engage and consult with Aboriginal People on land / resource use initiatives. This is 
another reason to build Aboriginal capacity in forestry. There is a need to meet the demand for requests made by industry and government for consultation. There is a need for skilled people to respond.

Globally, Traditional Ecological Knowledge (TEK) held by Indigenous Peoples is an essential component to holistic forest management that considers all forest values. Aboriginal foresters can assist communities in achieving capacity for responsible management of forest resources by balancing traditional and commercial uses for forests.

NAFA encourages Aboriginal youth to consider continuing education to lead them to work as professional foresters for First Nations, Tribal Councils or Aboriginal organizations. For more information about careers in forestry contact NAFA at 613-233-5563 or visit the website at www.nafaforestry.org.

\section{Careers In Forestry Video, 2004 National Aboriginal Forestry Association}

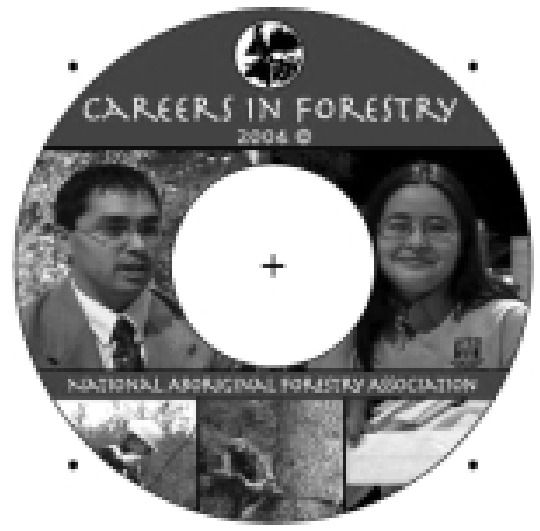

As First Nations gain increased control over an enlarged forested land base, the need for professionals in sustainable forest management becomes more critical. Recognizing this need for increased Aboriginal land managers in Canada, NAFA has undertaken the design of a video, which showcases the myriad of career opportunities available to Aboriginal students.

The forest products industry is Canada's leading manufacturing sector. It provides direct and indirect employment for more than 800000 workers. According to the Canadian Institute of Forestry (CIF) there are approximately 12000 practising foresters in Canada of whom 8500 have achieved Registered Professional Forester (RPF) status. Of those, NAFA estimates that only 80 are of Aboriginal descent and only 17 have the RPF designation.

Regarding Aboriginal interests, forest companies are beginning to view Aboriginal communities as long-term partners in forestry operations resulting in joint ven- tures. These ongoing processes, as they advance, will result in increased opportunities for forest management responsibility for First Nations and other Aboriginal communities. The need for trained professionals is critical in order to ensure communities are able to secure access to forests in traditional territories. This is essential in order to carry out traditional activities such as hunting and fishing as well as to maintain the fundamental connection to the land, which is the basis for traditional knowledge, Aboriginal cultures and economies.

This video can be used by educators, community leaders, and industry to create awareness amongst Aboriginal youth about the opportunities available locally, nationally and internationally.

This video, entitled Careers in Forestry, was created by NAFA to help influence Aboriginal students in obtaining a career in forest management. Aboriginal Business Canada (ABC) and the First Nations Forestry Program (FNFP) supported NAFA by funding the project.

NAFA members may view the Careers in Forestry video in digital format on our website at wwww.nafaforestry.org. The video is also available for purchase at NAFA for \$25 per copy.

For more information, please contact: Janet Pronovost, Office Administrator National Aboriginal Forestry Association 875 Bank Street Ottawa, ON K1S 3 W4 Tel: 613.233 .5563

Fax: 613.233.4329 Email:nafa@web.ca

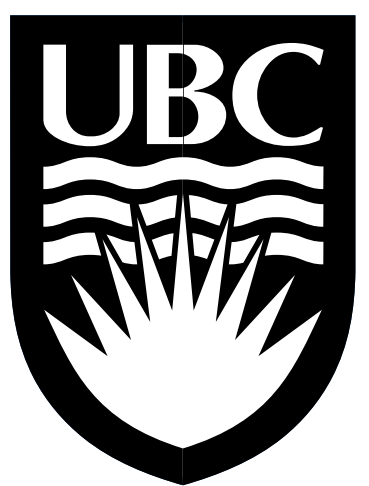

\section{A CIF/IFC Corporate Sustaining Member}

